\title{
Mineralogy Characteristic Study and Exploration on the Valuable Metals Enrichment of Coal Fly Ash
}

\author{
Tao Chen, ${ }^{1}$ Bo Yan, ${ }^{1}$ Li-li Li $\mathbb{D},{ }^{2}$ Zi-Ang Yan, ${ }^{3}$ Jun Wang, ${ }^{4}$ and Xian-ming Xiao ${ }^{5}$ \\ ${ }^{1}$ SCNU Environmental Research Institute, Guangdong Provincial Key Laboratory of Chemical Pollution and Environmental Safety \& \\ MOE Key Laboratory of Environmental Theoretical Chemistry, South China Normal University, Guangzhou 510006, China \\ ${ }^{2}$ College of Environmental Science and Engineering, Zhongkai University of Agriculture and Engineering, Guangzhou 510640, China \\ ${ }^{3}$ School of Chemical Engineering and Light Industry, Guangdong University of Technology, Guangzhou 510640, China \\ ${ }^{4}$ Shenzhen Zhongjin Lingnan Nonferrous Metals Co., Ltd., Shenzhen 518000, China \\ ${ }^{5}$ China University of Geosciences, Beijing 100083, China
}

Correspondence should be addressed to Li-li Li; lilili@gig.ac.cn

Received 30 May 2019; Accepted 7 August 2019; Published 27 October 2019

Copyright (c) 2019 Tao Chen et al. This is an open access article distributed under the Creative Commons Attribution License, which permits unrestricted use, distribution, and reproduction in any medium, provided the original work is properly cited.

\begin{abstract}
The separation and enrichment can be targeted to enrich in fly ash and reduce the cost of leaching and recovering of fly ash. Regarding their different properties, the single-component separation was used to obtain uncompleted burned carbon, glass microbeads, minerals, and other characteristic components from the ash. Also, the mineral composition of each component was analyzed by electron microscopy. The metal minerals were mainly concentrated in the mineral components. Besides, the electron probe microanalysis shows that the Pt content in the minerals of fly ash was significantly correlated with the metal contents of $\mathrm{Ni}$ and $\mathrm{Cu}$. After the obtainment of the characteristics of fly ash metal enrichment, the heavy minerals with $\mathrm{Cu}, \mathrm{Ni}, \mathrm{Pt}, \mathrm{Pd}$, and other target metal elements were enriched by gravity separation and flotation. The enrichment coefficients of $\mathrm{Cu}, \mathrm{Ni}, \mathrm{Pt}$, and $\mathrm{Pd}$ were $1.45,1.33$, 1.90 , and 1.60 , respectively, and the recovery rates were $77 \%, 81 \%, 97 \%$, and $88 \%$, respectively. Since the yield of heavy minerals obtained by separation was $62.24 \%$, it indicated the physical separation method could significantly reduce the cost of leaching and recovering of fly ash metal resources.
\end{abstract}

\section{Introduction}

The amount of fly ash produced is $5 \%-20 \%$ of the total mass of coal used. In 2017, the total amount of fly ash was 686 million tons in China. In addition to a large amount of carbon and hydrogen, coal also contains a variety of metals $[1,2]$. Its type is mainly related to coal strata. Through the analysis of the metal elements of different ore deposits, it is found that $\mathrm{Ca}, \mathrm{Ge}, \mathrm{Au}, \mathrm{Pt}, \mathrm{Sc}$, and other rare metal resources are contained in coal [3]. These metal elements enriched in fly ash can reach 4-10 times of the coal [4]. According to Wang et al. [3], the content of Au and Ga in fly ash was $1 \mu \mathrm{g} / \mathrm{g}$ and $50 \mu \mathrm{g} / \mathrm{g}$, respectively, which has a certain comprehensive recovery value. However, the conventional utilization rate of fly ash was less than 50\% [5], and utilized fly ash was still stored in the ash yard of power plants. Furthermore, fly ash also contains a variety of heavy metals. Izquierdo and Querol [6] and others have compared the leaching characteristics of more than 90 kinds of fly ash. It is found that these heavy metals in fly ash including $\mathrm{Cd}, \mathrm{Cr}, \mathrm{Co}, \mathrm{Cu}, \mathrm{Hg}, \mathrm{Ni}, \mathrm{Pb}, \mathrm{Sn}, \mathrm{Zn}$. As will be leached and transferred to the environment [7-10], thus causing severe environmental pollution $[11,12]$ when the environmental $\mathrm{pH}$ value decreases.

Metals in fly ash are mostly scattered elements associated with deposits, which have low contents and recovery values $[13,14]$, and there are up to 316 minerals in fly ash [15]. The metals could be recovered by leaching process effectively [16, 17]. Besides, heavy metal elements are transferred to the leachate [18]; thereby, the threat of the heavy metal pollution could be educed or even eliminated [19]. Acid was often used as leaching agent in the recovery of metals. However, most of the minerals of the ash were alkaline substances [20,21]. The alkaline material consumes a large amount of acid, leading to the high cost of leaching reagents. Therefore, the enrichment of metals and the removal of the alkaline substances should be carried before the leaching process. The enrichment could be realized by the mineral separation method [22], and the recovery value of rare metals would be promoted. However, 
the separation and enrichment of characteristic minerals for the ash are insufficient [23]. Fly ash mainly includes four components such as vitreous, magnetic material, hollow microbeads, and uncompleted burned carbon [15], and different components has significant differences of the minerals composition [1]. Thus, it is imperative to study the metals distribution characteristics and to study the separation technology for the enrichment of the rare metals in fly ash, aiming to provide some empirical basis for the comprehensive recovery of rare and precious metals from the fly ash.

\section{Materials and Methods}

2.1. Sampling Procedure and Sample Preparation. The Late Paleozoic coal seams in western Guizhou often contain platinum group elements [1], which have excellent research value of geoscience and comprehensive recovery. All samples were air dried at ambient temperature, lightly crushed, and followed by screening with a $2-\mathrm{mm}$ nylon sieve to remove coarse debris. After that, all the sieved samples were further mechanically pulverized and homogenized adequately so that all particles could pass through a 0.149 -mm nylon sieve for further chemical analysis. Shortly after processing, one representative composite tailing sample was prepared by thoroughly mixing all finely grounded ash samples employing the coning and quartering method to conduct the following tests.

2.2. Sorting Methods. The ball mill used in the flotation test is XMQ240-90 cone ball mill. The flotation equipment is XFG500 and XFG-1000 hanging flotation machine, and its impeller speed is $1500 \mathrm{r} / \mathrm{min}$. The pulp concentration for the flotation is $5 \%$, the collector is diesel, and the foaming agent is No. 2 oil. The gravity water selecting was processed with a beaker, the slurry concentration was $5 \%$, and aeration was carried out for 30 minutes using an aeration head. After standing for 2 hours, the upper substance and the bottom mud were taken, respectively. When shaker was used for specific gravity separation, the slurry concentration was $10 \%$, and the shaker frequency was $80 \mathrm{~s} / \mathrm{min}$.

2.3. Analysis Methods. An aliquot ( $0.5 \mathrm{~g})$ of coal fly ash samples was wet-digested in by microwave digestion equipment (WX-8000, EU microwave chemistry technology Co., Ltd.) under Method 3051A (US EPA, 2007). The metal concentrations were determined using flame atomic absorption spectrophotometer (FAAS, Hitachi ZA3000, Japan). For geochemical analysis, primary (Ca, Fe, Al, Mg, Si, $\mathrm{Ca}$, and $\mathrm{Mn}$ ) elements were determined by X-ray fluorescence spectroscopy (XRF, Philips PW1480, America) after the loss on ignition (LOI) measurement at $1100^{\circ} \mathrm{C}$. Scanning electron microscopy (SEM) equipped with an energy-dispersive X-ray (EDX) detector (S-4800, Hitachi, Japan) was operated for the surface mineralogical investigation. The electron probe (JXA8100, JEOL, Japan) was used for the analysis of the microarea distribution characteristics of metals. The analysis for the specific gravity and the specific surface was carried with the
TABLE 1: Elemental analysis of fly ash.

\begin{tabular}{lcccccc}
\hline $\mathrm{SiO}_{2} \%$ & $\mathrm{Al}_{2} \mathrm{O}_{3} \%$ & $\mathrm{CaO} \%$ & $\mathrm{MgO} \%$ & $\mathrm{~S} \%$ & $\mathrm{Fe} \%$ & $\mathrm{Zn} \%$ \\
\hline 42.18 & 3.44 & 11.07 & 0.11 & 0.61 & 16.39 & 0.15 \\
$\mathrm{As} \mathrm{g} / \mathrm{t}$ & $\mathrm{Hg} \mathrm{g} / \mathrm{t}$ & $\mathrm{Pb} \mathrm{g/t}$ & $\mathrm{Ag} \mathrm{g/t}$ & $\mathrm{Rb} \mathrm{g/t}$ & $\mathrm{Cr} \mathrm{g/t}$ & $\mathrm{Cd} \mathrm{g} / \mathrm{t}$ \\
225.27 & 0.59 & 382.41 & 3.17 & 29.42 & 77.92 & $\mathrm{Nd}$ \\
$\mathrm{Cu} \mathrm{g} / \mathrm{t}$ & $\mathrm{Mn} \mathrm{g} / \mathrm{t}$ & $\mathrm{Ni} \mathrm{g} / \mathrm{t}$ & $\mathrm{Ga} \mathrm{g} / \mathrm{t}$ & $\mathrm{Pt} \mathrm{g} / \mathrm{t}$ & $\mathrm{Pd} \mathrm{g} / \mathrm{t}$ & $\mathrm{LOI} \%$ \\
1050.52 & 66.83 & 533.19 & 1.38 & 0.10 & 0.05 & 9.14 \\
\hline
\end{tabular}

true density tester (G-DenPyc2900, Beijing) and the surface area and porosity analyzer (micromeritics, USA).

\section{Results and Discussion}

3.1. Physicochemical Properties of Fly Ash. As shown in Table 1 , the specific gravity of fly ash is $1.85 \mathrm{~g} / \mathrm{cm}^{3}$, and the specific surface area is $3180 \mathrm{~cm}^{2} / \mathrm{g}$ respectively. The Ca content in fly ash is $11 \%$, and it is the low calcium content ash. The ratio of $\left[(\mathrm{CaO}+\mathrm{MgO}) /\left(\mathrm{SiO}_{2}+\mathrm{Al}_{2} \mathrm{O}_{3}\right)\right]$ in fly ash is 0.24 ; thus, the ash belongs to acid ash and has typical characteristics of ultrabasic rock deposits [24]. The content of Pt and Pd in fly ash is $0.10 \mathrm{~g} / \mathrm{t}$ and $0.05 \mathrm{~g} / \mathrm{t}$, respectively. The typical geological characteristics of the ash can be further proved with the discovery of Pt group elements [3]. Besides the Pt group elements, the content of $\mathrm{Cu}$ and $\mathrm{Ni}$ can reach $0.15 \%$. The Fe content in this sample can reach $16 \%$. These metals have a high recovery value. However, the cost for the direct leaching recovery would be higher than recycled products for the high content of alkaline substances such as $\mathrm{Ca}$ and $\mathrm{Mg}$ [25]. It is a necessity to study the metal distribution characteristics.

3.2. Microscopic Characteristics of Fly Ash Components. The micromorphology of fly ash samples under the secondary electron and secondary electron + back scattering states of scanning electron microscopy was shown in Figure 1. It can be seen that fly ash contains three components: spherical hollow microbeads (Figure 1(a)), uncompleted burned carbon (Figure 1(a)), and minerals (Figure 1(b)). Through backscattering, it can be seen that some metallic minerals are contained in the minerals. The physical and chemical properties of the three components are quite different and easy to separate [23]. Thus, the single-component sorting tests will first proceed. The sorting recovery rates for the single component would not be recorded, because the primary purpose of mono-component separation tests was to obtain the single component as pure as possible.

The uncompleted burned carbon was obtained by the chosen flotation. Its electron microscope images were shown in Figures 1(c) and 1(d). It can be seen that the space between multi-particles of the uncompleted burned carbon is small, the particles are porous materials, and the BSE analysis does not contain the metal substance. Since the composition of conductive plastic for EDS is organic C, the energy spectrum analysis of the uncompleted burned carbon was not performed. 


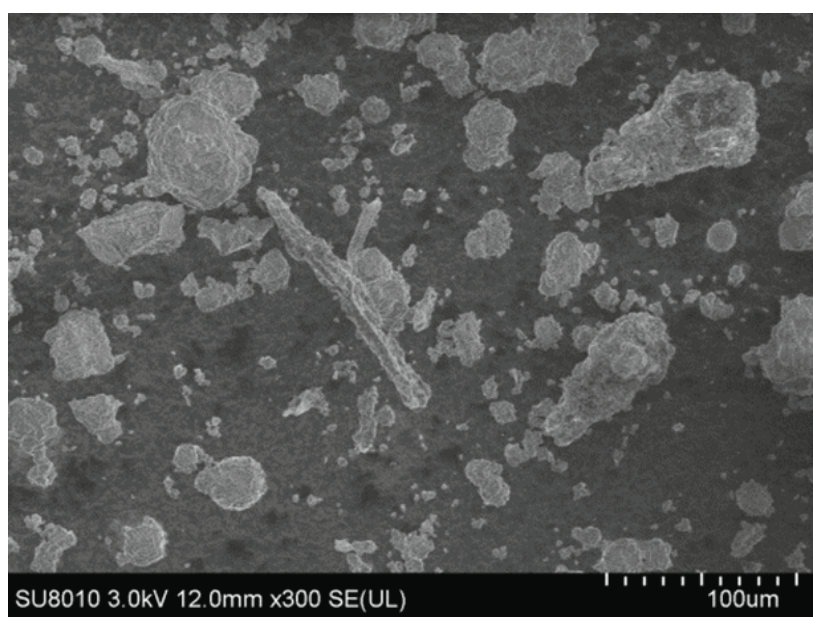

(a)

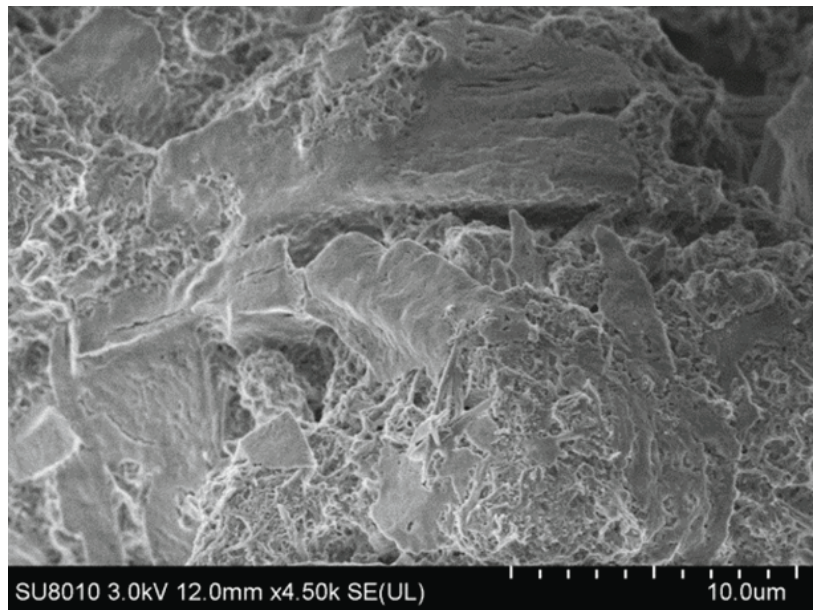

(c)

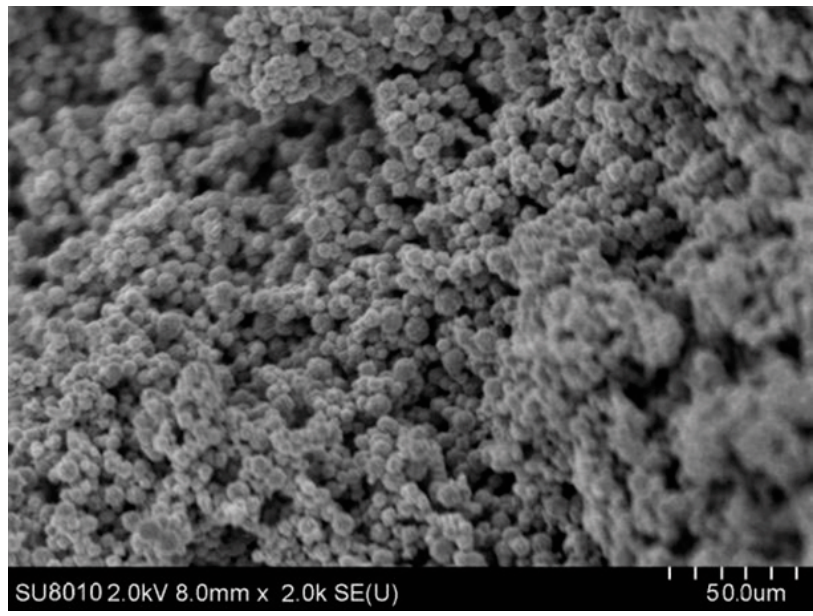

(e)

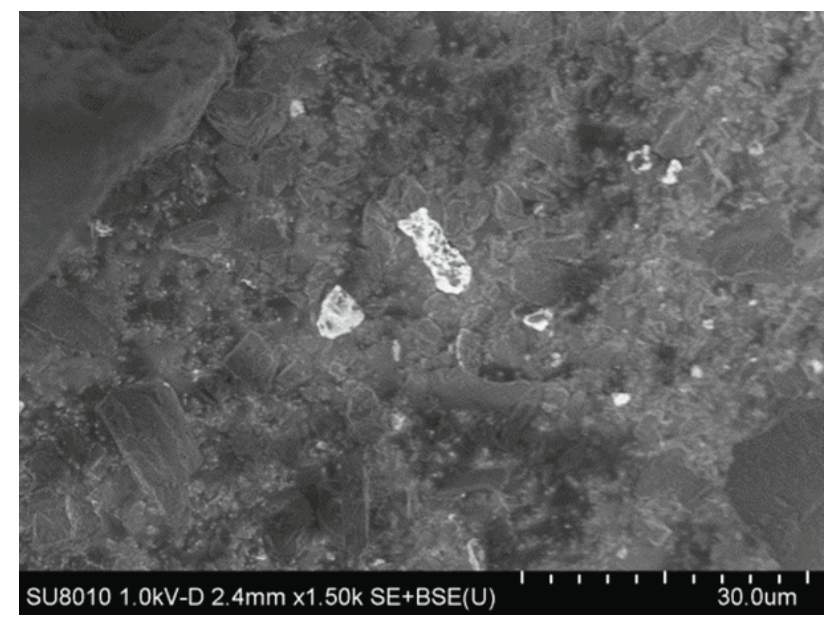

(b)

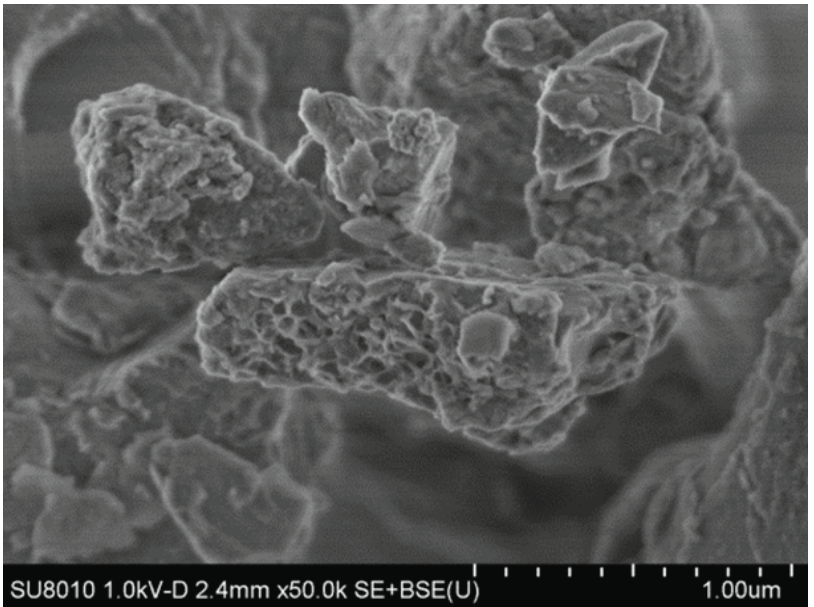

(d)

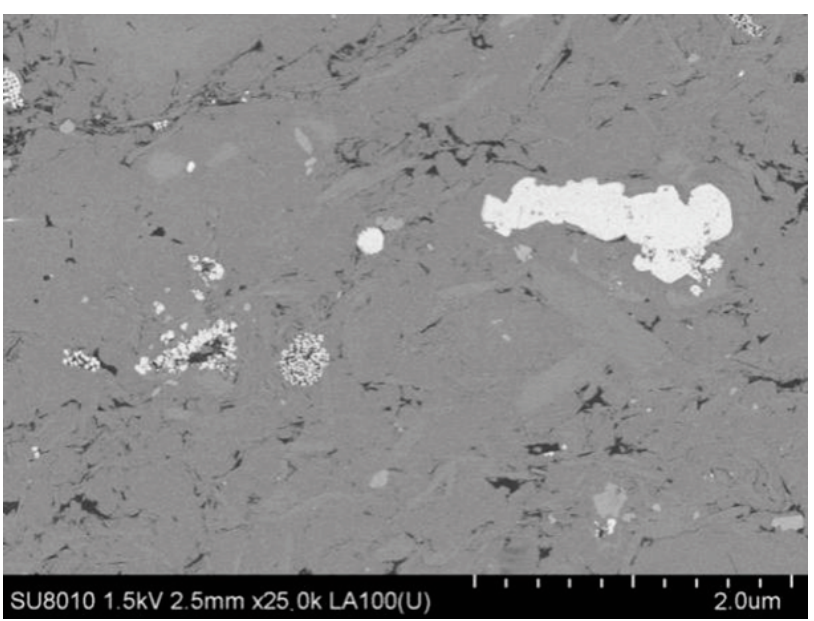

(f)

Figure 1: Continued. 


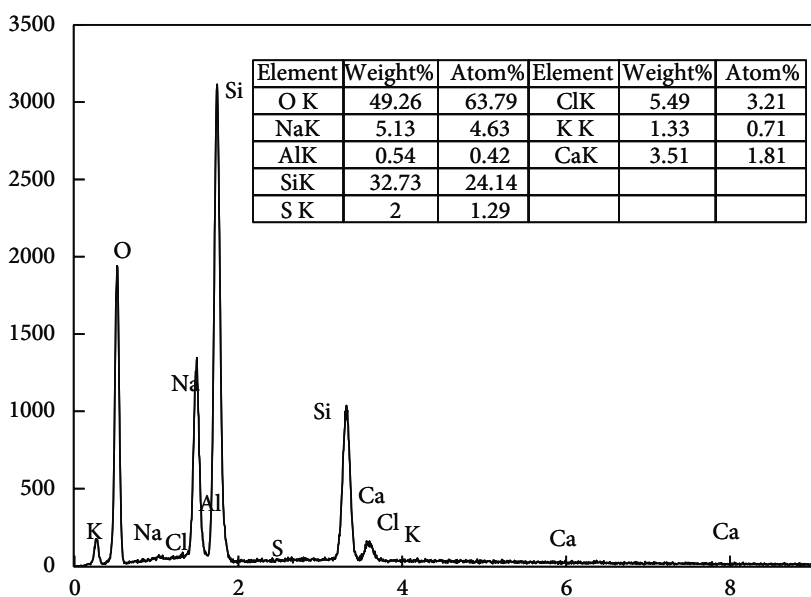

(g)

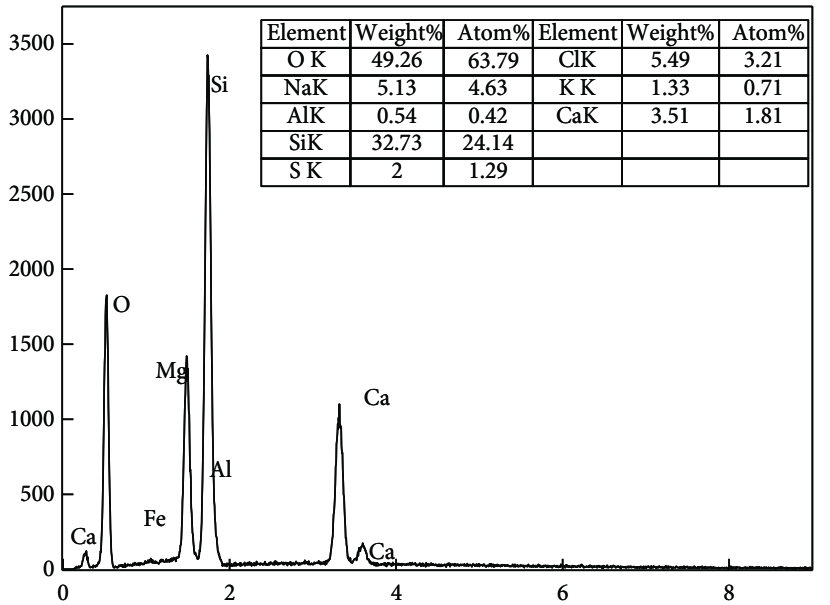

(i)

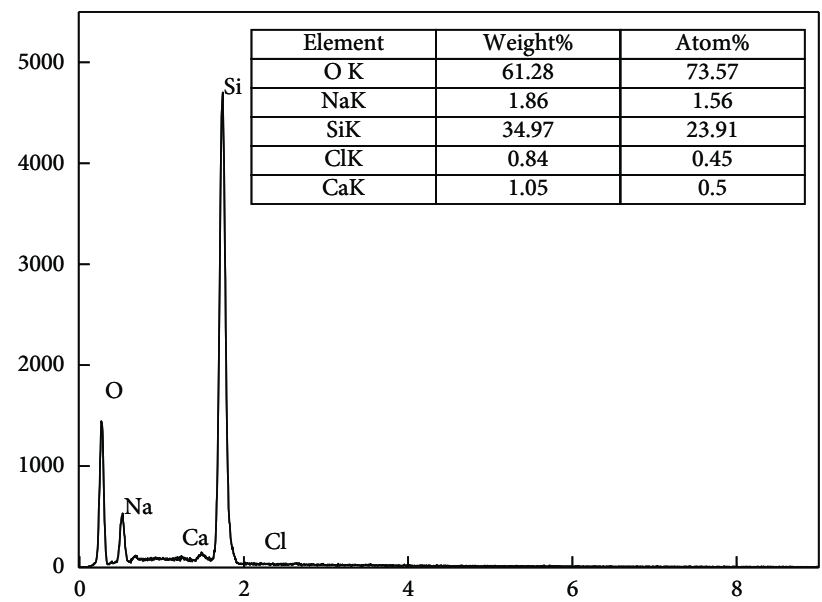

(h)

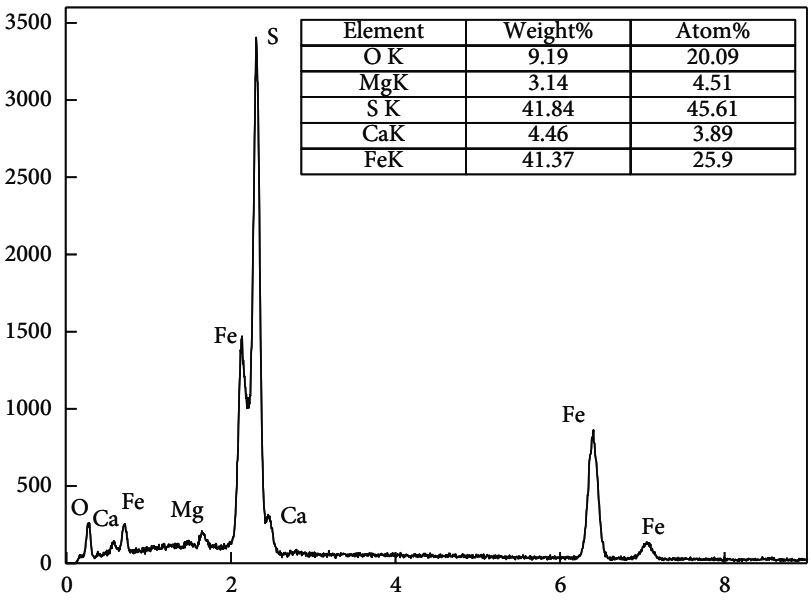

(j)

FIGURE 1: Photomicrograph and energy spectrum of the fly ash and its single components.
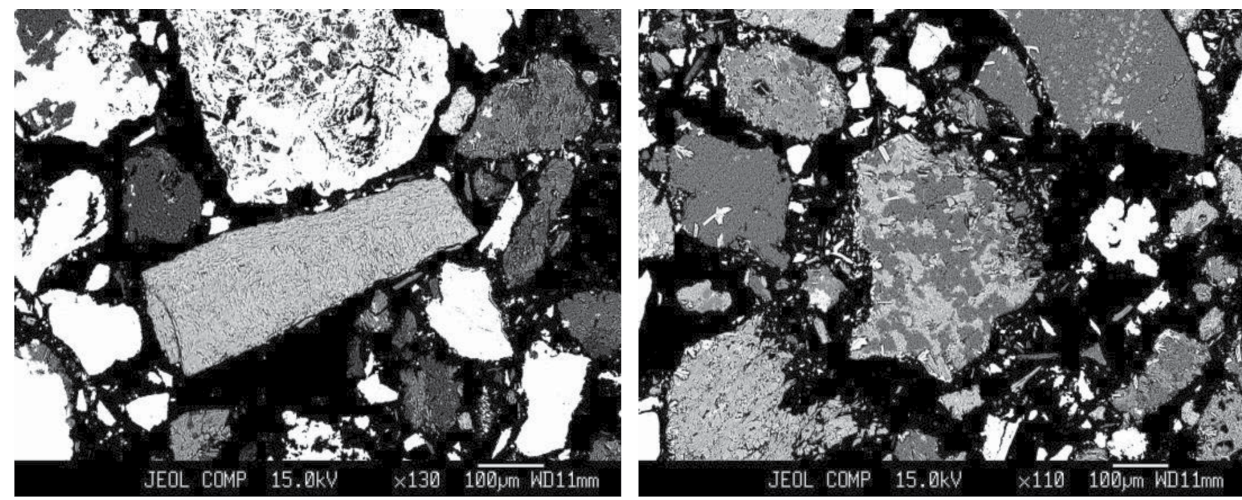

FiguRE 2: Electron probe photographs of the minerals.

The uncompleted burned carbon was removed from fly ash by flotation firstly; the obtained flotation tailings were separated by gravity sedimentation. After three times of gravity separation, the materials still floating on the water surface were dehydrated and dried to obtain hollow microbeads. Figure 1(e) shows the microscopic characteristics of hollow microbeads. It can be seen that the microbeads are all fine particles, and are mostly gathered together to form larger particles. The EDS results were shown in Figures 1(g) and $1(\mathrm{~h})$. It can be seen that the hollow microsphere were mostly alumino-silicate materials or silicon oxide, and most of the materials are glass phases, that is, amorphous phases. Metal minerals were not found on hollow microbeads under BSE. 
TABLE 2: Chemical composition of the electron probe points for the minerals (\%).

\begin{tabular}{lccccc}
\hline Point & 1 & 2 & 3 & 4 & 5 \\
\hline $\mathrm{MgO}$ & 1.148 & 0.076 & 0.003 & 0.004 & 6.19 \\
$\mathrm{~K}_{2} \mathrm{O}$ & 0.191 & 0.078 & 0.055 & 0.009 & 0.043 \\
$\mathrm{SiO}_{2}$ & 1.611 & 90.415 & 0.013 & 97.649 & 22.38 \\
$\mathrm{Cr}_{2} \mathrm{O}_{3}$ & 0.346 & 0.042 & 0.09 & 0.137 & $/$ \\
$\mathrm{Al}_{2} \mathrm{O}_{3}$ & 0.657 & 0.263 & 0.01 & 0.055 & 19.55 \\
$\mathrm{CaO}$ & 0.072 & 0.04 & 30.11 & 0.014 & $/$ \\
$\mathrm{MnO}$ & $/$ & $/$ & $/$ & 0.005 & 0.58 \\
$\mathrm{PbO}$ & 1.449 & 0.228 & 0.23 & 0.036 & 0.55 \\
$\mathrm{SO}$ & 23.37 & 0.481 & 33.406 & 0.102 & 0.15 \\
$\mathrm{CuO}$ & 0.226 & 0.012 & 0.59 & $/$ & 0.53 \\
$\mathrm{NiO}$ & $/$ & $/$ & 1.12 & $/$ & 0.67 \\
$\mathrm{Rb} 2 \mathrm{O}$ & $/$ & $/$ & $/$ & $/$ & $/$ \\
$\mathrm{ZnO}$ & 55.569 & 0.341 & 0.5838 & 1.036 & $/$ \\
$\mathrm{Na}_{2} \mathrm{O}$ & 2.001 & 0.022 & - & 0.006 & 0.01 \\
$\mathrm{FeO}$ & 4.547 & 0.349 & 30.75 & 0.376 & 46.932 \\
$\mathrm{PtO}_{2}$ & $/$ & $/$ & 0.58 & $/$ & 0.41 \\
$\mathrm{Total}$ & 91.187 & 92.347 & 97.5408 & 99.429 & 97.995 \\
\hline
\end{tabular}

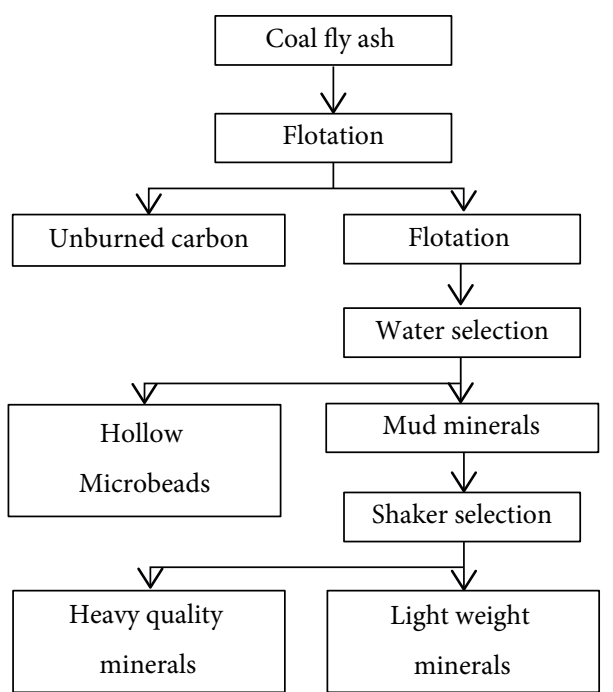

Figure 3: Physical selection test procedure for the coal fly ash.

TABLE 3: Component correlation analysis.

\begin{tabular}{lccccccccccc}
\hline & $\mathrm{SiO}_{2}$ & $\mathrm{Al}_{2} \mathrm{O}_{3}$ & $\mathrm{CaO}$ & $\mathrm{MnO}$ & $\mathrm{PbO}$ & $\mathrm{SO}_{3}$ & $\mathrm{CuO}$ & $\mathrm{NiO}$ & $\mathrm{ZnO}$ & $\mathrm{FeO}$ & $\mathrm{PtO}_{2}$ \\
\hline $\mathrm{SiO}_{2}$ & 1.00 & -0.24 & -0.49 & -0.23 & -0.62 & -0.77 & -0.83 & -0.62 & -0.47 & -0.59 & -0.62 \\
$\mathrm{Al}_{2} \mathrm{O}_{3}$ & -0.24 & 1.00 & -0.27 & $0.99^{* *}$ & 0.08 & -0.40 & 0.51 & 0.32 & -0.23 & 0.79 & 0.41 \\
$\mathrm{CaO}$ & -0.49 & -0.27 & 1.00 & -0.25 & -0.27 & 0.78 & 0.64 & 0.83 & -0.25 & 0.37 & 0.77 \\
$\mathrm{MnO}$ & -0.23 & $0.99^{* *}$ & -0.25 & 1.00 & 0.05 & -0.41 & 0.51 & 0.34 & -0.26 & 0.80 & 0.42 \\
$\mathrm{PbO}$ & -0.62 & 0.08 & -0.27 & 0.05 & 1.00 & 0.37 & 0.13 & -0.23 & $0.94^{*}$ & -0.04 & -0.22 \\
$\mathrm{SO}_{3}$ & -0.77 & -0.40 & 0.78 & -0.41 & 0.37 & 1.00 & 0.54 & 0.52 & 0.42 & 0.14 & 0.46 \\
$\mathrm{CuO}$ & -0.83 & 0.51 & 0.64 & 0.51 & 0.13 & 0.54 & 1.00 & $0.92^{*}$ & -0.10 & $0.91^{*}$ & $0.94^{*}$ \\
$\mathrm{NiO}$ & -0.62 & 0.32 & 0.83 & 0.34 & -0.23 & 0.52 & $0.92^{*}$ & 1.00 & -0.39 & 0.83 & $0.99^{* *}$ \\
$\mathrm{ZnO}$ & -0.47 & -0.23 & -0.25 & -0.26 & $0.94^{*}$ & 0.42 & -0.10 & -0.39 & 1.00 & -0.33 & -0.40 \\
$\mathrm{FeO}$ & -0.59 & 0.79 & 0.37 & 0.80 & -0.04 & 0.14 & $0.91^{*}$ & 0.83 & -0.33 & 1.00 & 0.88 \\
$\mathrm{PtO}_{2}$ & -0.62 & 0.41 & 0.77 & 0.42 & -0.22 & 0.46 & $0.94^{*}$ & $0.99^{* *}$ & -0.40 & 0.88 & 1.00 \\
\hline
\end{tabular}

${ }^{* *}$ Significantly correlated at 0.01 level (both sides), ${ }^{*}$ Significantly correlated at 0.05 level (both sides).

TABLE 4: Metal recovery tests of the fly ash.

\begin{tabular}{lcccccccccccc}
\hline & Yield\% & $\mathrm{Fe} \%$ & $\mathrm{SiO}_{2} \%$ & $\mathrm{Zn} \%$ & $\mathrm{Pbg} / \mathrm{t}$ & $\mathrm{Agg} / \mathrm{t}$ & $\mathrm{Cug} / \mathrm{t}$ & $\mathrm{Nig} / \mathrm{t}$ & $\mathrm{Gag} / \mathrm{t}$ & $\mathrm{Ptg} / \mathrm{t}$ & $\mathrm{Pdg} / \mathrm{t}$ \\
\hline Coal fly ash & 100 & 16.39 & 42.18 & 0.15 & 382.41 & 3.17 & 1050.52 & 533.19 & 1.38 & 0.1 & 0.05 \\
Unburned carbon & 4.55 & 0.55 & 12.31 & 0.01 & 15.23 & $\mathrm{nd}$ & 15.37 & 8.41 & 0.18 & $\mathrm{nd}$ & $\mathrm{nd}$ \\
Hollow microbeads & 1.72 & 1.54 & 61.53 & 0.05 & 20.07 & 0.52 & 3.71 & 0.58 & 0.35 & $\mathrm{nd}$ & $\mathrm{nd}$ \\
Lightweight minerals & 31.49 & 10.55 & 50.19 & 0.16 & 255.41 & 1.09 & 886.42 & 317.66 & 1.43 & 0.01 & 0.02 \\
Heavy quality minerals & 62.24 & 22.31 & 39.52 & 0.21 & 439.25 & 3.86 & 1528.62 & 710.38 & 2.13 & 0.19 & 0.08 \\
\hline & & $\mathrm{Fe}$ & $\mathrm{SiO}_{2}$ & $\mathrm{Zn}$ & $\mathrm{Pb}$ & $\mathrm{Ag}$ & $\mathrm{Cu}$ & $\mathrm{Ni}$ & $\mathrm{Ga}$ & $\mathrm{Pt}$ & $\mathrm{Pd}$ \\
Unburned carbon & $\%$ & 0.14 & 1.33 & 0.25 & 0.20 & 0.00 & 0.06 & 0.07 & 0.46 & 0.00 & 0.00 \\
Hollow microbeads & $\%$ & 0.15 & 2.52 & 0.47 & 0.10 & 0.32 & 0.01 & 0.00 & 0.34 & 0.00 & 0.00 \\
Lightweight minerals & $\%$ & 19.25 & 37.61 & 27.62 & 22.67 & 12.46 & 22.67 & 18.44 & 25.15 & 2.59 & 11.23 \\
Heavy quality minerals & $\%$ & 80.45 & 58.54 & 71.66 & 77.04 & 87.21 & 77.27 & 81.49 & 74.05 & 97.41 & 88.77 \\
Total recovery rate & $\%$ & 105.30 & 99.62 & 121.60 & 92.79 & 86.90 & 117.21 & 101.76 & 129.73 & 121.41 & 112.18 \\
\hline
\end{tabular}


The residues after sorting of the hollow microbeads were defined as the mineral in the fly ash; the minerals were not sorted with its unique physical properties. Thus, its composition would be complicated, and the mineralogy flakes for the minerals were prepared for the comprehensive microscopic observation (Figure 1(f)). It can be seen that the minerals include nonmetallic minerals and metallic minerals. The EDS (Figures 1(i) and $1(j)$ ) showed that the minerals were mainly composed of iron-bearing minerals. Since pyrite is easier to be found in BSE electron microscopy analysis, the energy spectrum data mainly show pyrite minerals.

3.3. Probe Analysis for the Minerals of the Fly Ash. Probe analysis for the minerals of the fly ash was shown in Figure 2 and the chemical composition of the probe point was shown in Table 2. It can be seen that the particle size of the minerals was about $10 \mu \mathrm{m}$, and the components of the minerals were abundant. Five feature point probe analyses were chosen for the discussion (Table 2). As the results of the probe, it can be found that the probe point 1 was the sphalerite, probe points 2 and 4 were the $\mathrm{SiO}_{2}$, and probe points 3 and 5 were some silicate ores with iron oxide ore. Pt had been detected within the probe points 3 and 5, also, the $\mathrm{Ni}$ and $\mathrm{Cu}$ had been detected.

The correlation analysis of element concentration was shown in Table 3. It can be seen from the analysis that $\mathrm{Pt}$ is significantly correlated with $\mathrm{Ni}$ and $\mathrm{Cu}$, and the correlation coefficients are 0.99 and 0.94 , respectively. In addition, $\mathrm{Pt}$ is poorly correlated with major ore-forming elements such as $\mathrm{Ca}, \mathrm{Al}$, and $\mathrm{Si}$. It can be concluded that Pt in fly ash is mainly associated with metal elements such as $\mathrm{Ni}$ and $\mathrm{Cu}$.

3.4. Research on the Recovery of Valuable Elements. As the SEM analysis, metal minerals were not found out within the pure feature single component. With the electron probe analysis of the minerals, Pt element was found in the minerals. Furthermore, $\mathrm{Pt}$ was closely correlated with $\mathrm{Ni}$ and $\mathrm{Cu}$. In order to recover the $\mathrm{Pt}$ from the fly ash, the separation to enrich Pt was tested; the separation process was shown in Figure 3.

The yield and also the metal grade of the separation were shown in Table 4 . The total recoveries of the analyzed indicators were $86 \%-130 \%$ of the original pulverized coal ash, and the analytical results were ideal. The metals such as $\mathrm{Cu}, \mathrm{Ni}, \mathrm{Pt}$, and $\mathrm{Pd}$ in heavy minerals were enriched by $1.45,1.33,1.90$, and 1.60 times, and the recovery rates of target elements such as $\mathrm{Cu}, \mathrm{Ni}, \mathrm{Pt}$, and $\mathrm{Pd}$ in heavy minerals were $77 \%, 81 \%, 97 \%$, and $88 \%$, respectively. The uncompleted burned carbon, hollow microbeads, and other products obtained by separation could be recycled again. It explained that the use of the separation process route could not only enrich the elements of $\mathrm{Cu}$, $\mathrm{Ni}, \mathrm{Pt}$, and $\mathrm{Pd}$ in fly ash but also realize the comprehensive utilization of fly ash.

\section{Conclusions}

Pt was detected within the coal fly ash which was the coal seams in Western Guizhou Province. The uncompleted burned carbon and glass microbeads can be sorted with the single component separation process. The mineralogical analysis shows that uncompleted burned carbon was porous substances and glass microbeads were mainly the amorphous phase of silicate. Furthermore, the minerals could be concentrated with the sorting of the uncompleted burned carbon and also the glass microbeads. Pt element was found in the minerals, and $\mathrm{Pt}$ was closely correlated with $\mathrm{Ni}$ and $\mathrm{Cu}$ with the analysis of electron microprobe. Heavy minerals with $\mathrm{Cu}, \mathrm{Ni}, \mathrm{Pt}, \mathrm{Pd}$ and other metals could be separated with flotation and the gravity separation from the coal fly ash, the enrichment coefficients are $1.45,1.33,1.90$ and 1.60 times, respectively, and the recovery rates are $77 \%, 81 \%, 97 \%$ and $88 \%$, respectively. It shows that the elements such as $\mathrm{Cu}, \mathrm{Ni}, \mathrm{Pt}$ and $\mathrm{Pd}$ could be concentrated by the separation route, thus, the comprehensive utilization of fly ash could be realized.

\section{Data Availability}

The data used to support the findings of this study are included within the article.

\section{Conflicts of Interest}

The authors declare that they have no competing, personal and financial interests in this manuscript.

\section{Acknowledgments}

This work was supported by the National Natural Science Foundation of China Youth Fund (No. 41503116), National Key Research and Development Plan (2018YFC1802803), Guangdong Provincial Science and Technology Program (2015B020237003), Guangdong Natural Science Foundation (No. 2017A03031D05 and 2017B030314057), and Foshan Science and Technology Program (2016AG100541).

\section{References}

[1] S. Dai, D. Ren, C. L. Chou, R. B. Finkelman, V. V. Seredin, and Y. Zhou, "Geochemistry of trace elements in chinese coals: a review of abundances, genetic types, impacts on human health, and industrial utilization," International Journal of Coal Geology, vol. 94, pp. 3-21, 2012.

[2] S. Dai, L. Zhao, S. Peng, C. Chou, X. Wang, and Y. Zhang, "Abundances and distribution of minerals and elements in high-alumina coal fly ash from the jungar power plant, inner mongolia, China," International Journal of Coal Geology, vol. 81, no. 4, pp. 320-332, 2010.

[3] W. Wang, S. Sang, W. Hao et al., "A cut-off grade for gold and gallium in coal," Fuel, vol. 147, pp. 62-66, 2015.

[4] O. Font, X. Querol, A. Lopez-Soler et al., "Ge extraction from gasification fly ash," Fuel, vol. 84, no. 11, pp. 1384-1392, 2005.

[5] U. Bhattacharjee and T. C. Kandpal, "Potential of fly ash utilisation in India," Energy, vol. 27, no. 2, pp. 151-166, 2002.

[6] M. Izquierdo and X. Querol, "Leaching behaviour of elements from coal combustion fly ash: an overview," International Journal of Coal Geology, vol. 94, pp. 54-66, 2012. 
[7] A. M. Cardoso, M. B. Horn, L. S. Ferret, C. M. N. Azevedo, and M. Pires, "Integrated synthesis of zeolites $4 \mathrm{~A}$ and $\mathrm{Na}-\mathrm{P} 1$ using coal fly ash for application in the formulation of detergents and swine wastewater treatment," Journal of Hazardous Materials, vol. 287, pp. 69-77, 2015.

[8] T. Chen and B. Yan, "Fixation and partitioning of heavy metals in slag after incineration of sewage sludge," Waste Management, vol. 32, no. 5, pp. 957-964, 2012.

[9] K. Komonweeraket, B. Cetin, C. H. Benson, A. H. Aydilek, and T. B. Edil, "Leaching characteristics of toxic constituents from coal fly ash mixed soils under the influence of $\mathrm{pH}$," Waste Management, vol. 38, pp. 174-184, 2015.

[10] J. Reinik, N. Irha, E. Steinnes, G. Urb, J. Jefimova, and E. Piirisalu, "Release of 22 elements from bottom and fly ash samples of oil shale fueled PF and CFB boilers by a two-cycle standard leaching test," Fuel Processing Technology, vol. 124, pp. 147-154, 2014.

[11] A. Kapička, E. Petrovský, S. Ustjak, and K. Macháčková, "Proxy mapping of fly-ash pollution of soils around a coal-burning power plant: a case study in the Czech Republic," Journal of Geochemical Exploration, vol. 66, no. 1-2, pp. 291-297, 1999.

[12] G. Zhang, Y. Xi, Y. Xue, X. Xiang, and X. Wen, "Coal fly ash effluent affects the distributions of brachionus calyciflorus sibling species," Ecotoxicology and Environmental Safety, vol. 112, pp. 60-67, 2015.

[13] O. Font, X. Querol, R. Juan et al., "Recovery of gallium and vanadium from gasification fly ash," Journal of Hazardous Materials, vol. 139, no. 3, pp. 413-423, 2007.

[14] Z. T. Yao, X. S. Ji, P. K. Sarker et al., "A comprehensive review on the applications of coal fly ash," Earth-Science Reviews, vol. 141, pp. 105-121, 2015.

[15] S. V. Vassilev and C. G. Vassileva, "Methods for characterization of composition of fly ashes from coal-fired power stations: a critical overview," Energy Fuels, vol. 19, no. 3, pp. 1084-1098, 2005.

[16] L. C. Ram and R. E. Masto, "Fly ash for soil amelioration: a review on the influence of ash blending with inorganic and organic amendments," Earth-Science Reviews, vol. 128, pp. 52$74,2014$.

[17] M. J. Rushwaya and S. Ndlovu, "Purification of coal fly ash leach liquor by solvent extraction: identification of influential factors using design of experiments," International Journal of Mineral Processing, vol. 164, pp. 11-20, 2017.

[18] J. M. Chimenos, A. I. Fernández, R. V. Zermeño, O. Font, $\mathrm{X}$. Querol, and P. Coca, "Arsenic and antimony removal by oxidative aqueous leaching of IGCC fly ash during germanium extraction," Fuel, vol. 112, pp. 450-458, 2013.

[19] F. Jiao, L. Zhang, Z. Dong, T. Namioka, N. Yamada, and Y. Ninomiya, "Study on the species of heavy metals in MSW incineration fly ash and their leaching behavior," Fuel Processing Technology, vol. 152, pp. 108-115, 2016.

[20] S.-J. Han, H. J. Im, and J. H. Wee, "Leaching and indirect mineral carbonation performance of coal fly ash-water solution system," Applied Energy, vol. 142, pp. 274-282, 2015.

[21] J. Kalembkiewicz and U. Chmielarz, "Functional speciation and leach ability of titanium group from industrial fly ash," Fuel, vol. 123, pp. 73-78, 2014.

[22] T. Chen, B. Yan, C. Lei, and X. M. Xiao, "Metal recovery from the copper sulfide tailing with leaching and fractional precipitation technology," Hydrometallurgy, vol. 148, pp. 178-182, 2014.
[23] T. Hirajima, H. T. B. M. Petrus, Y. Oosako, M. Nonaka, K. Sasaki, and T. Ando, "Recovery of cenospheres from coal fly ash using a dry separation process: separation estimation and potential application," International Journal of Mineral Processing, vol. 95, no. 1-4, pp. 18-24, 2010.

[24] T. Xie and T. Ozbakkaloglu, "Behavior of low-calcium fly and bottom ash-based geopolymer concrete cured at ambient temperature," Ceramics International, vol. 41, no. 4, pp. 59455958, 2015.

[25] F. A. Torralvo and F. C. Pereira, "Recovery of germanium from real fly ash leachates by ion-exchange extraction," Minerals Engineering, vol. 24, no. 1, pp. 35-41, 2011. 


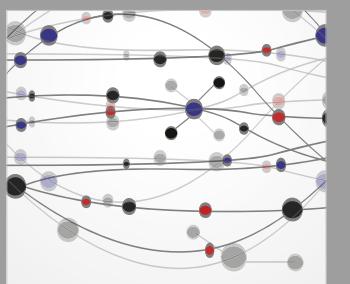

The Scientific World Journal
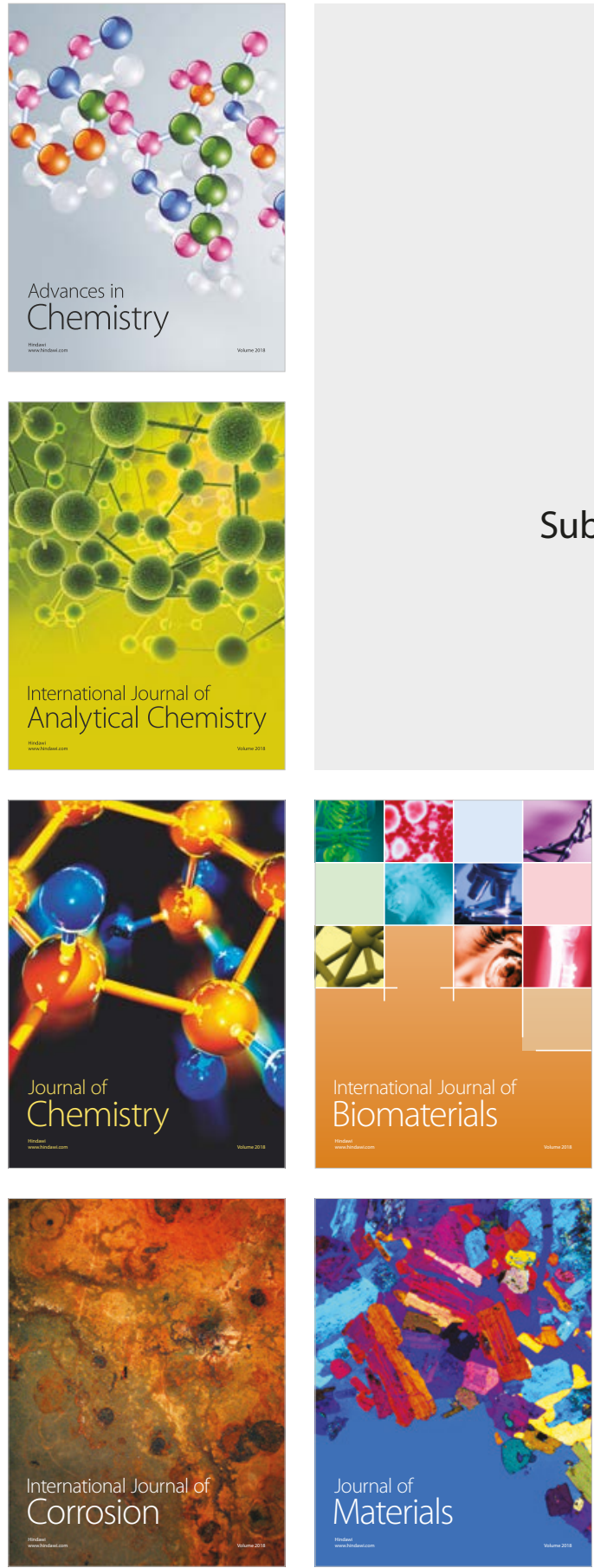

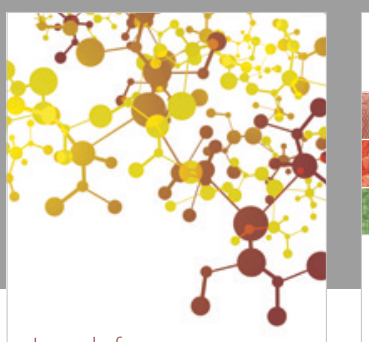

Journal of

Applied Chemistry
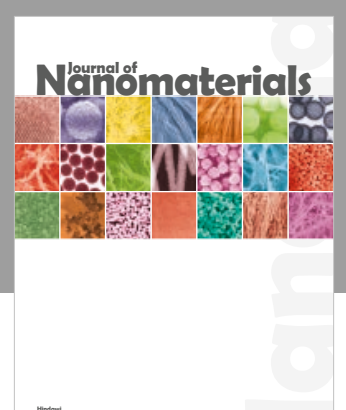

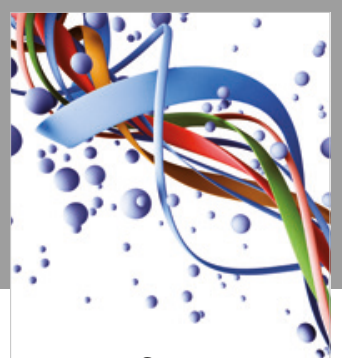

Scientifica

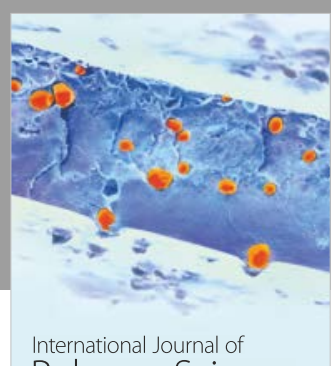

Polymer Science

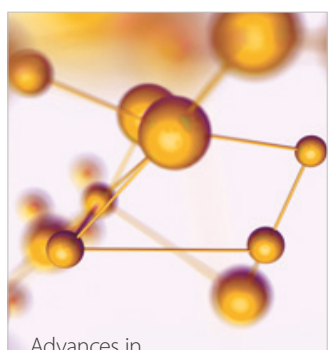

Physical Chemistry
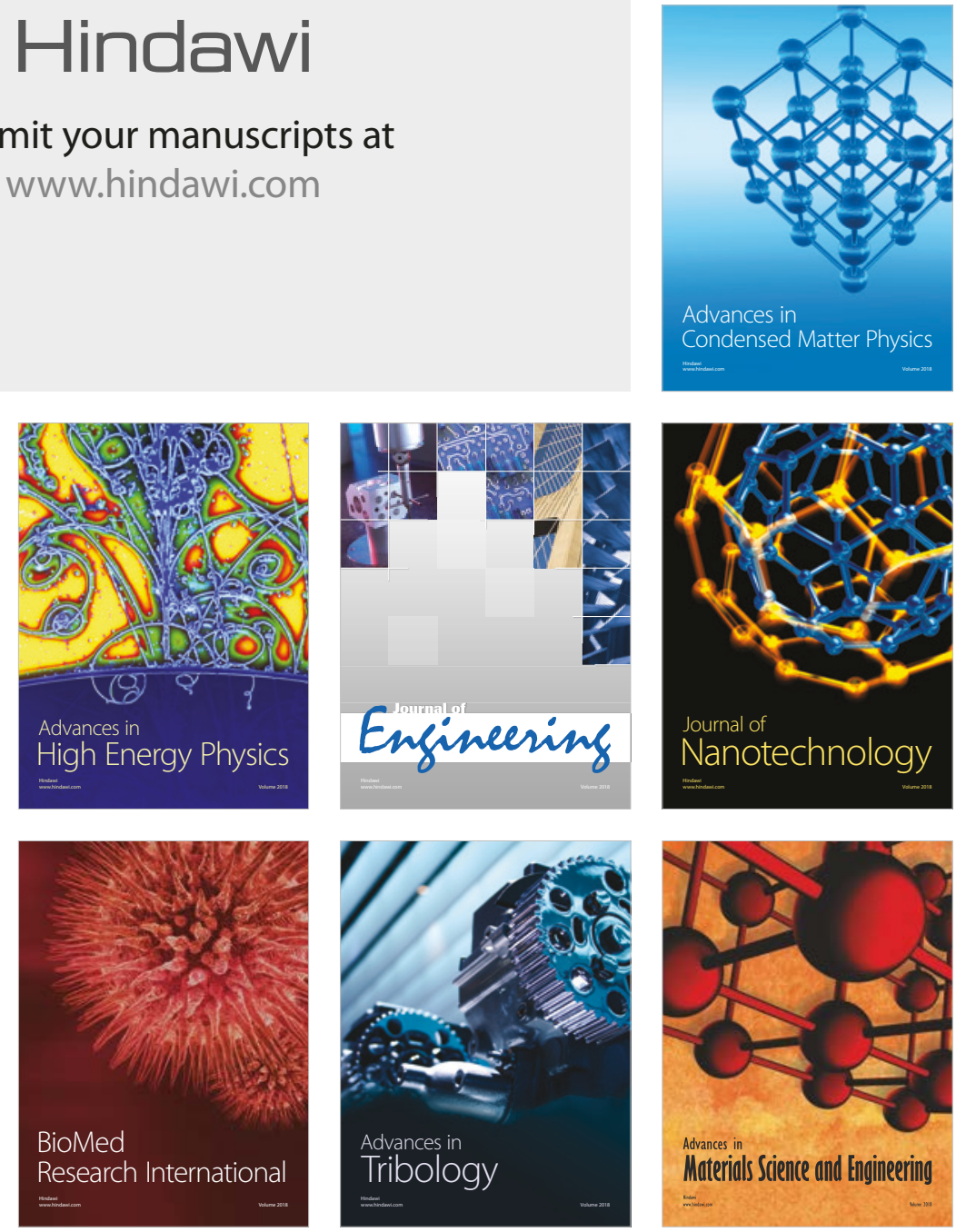